\title{
Visualizing chemical functionality in plant cell walls
}

Yining Zeng ${ }^{1,2^{*}} \mathbb{D}$, Michael E. Himmel ${ }^{1,2}$ and Shi-You Ding ${ }^{3}$

\begin{abstract}
Understanding plant cell wall cross-linking chemistry and polymeric architecture is key to the efficient utilization of biomass in all prospects from rational genetic modification to downstream chemical and biological conversion to produce fuels and value chemicals. In fact, the bulk properties of cell wall recalcitrance are collectively determined by its chemical features over a wide range of length scales from tissue, cellular to polymeric architectures. Microscopic visualization of cell walls from the nanometer to the micrometer scale offers an in situ approach to study their chemical functionality considering its spatial and chemical complexity, particularly the capabilities of characterizing biomass non-destructively and in real-time during conversion processes. Microscopic characterization has revealed heterogeneity in the distribution of chemical features, which would otherwise be hidden in bulk analysis. Key microscopic features include cell wall type, wall layering, and wall composition - especially cellulose and lignin distributions. Microscopic tools, such as atomic force microscopy, stimulated Raman scattering microscopy, and fluorescence microscopy, have been applied to investigations of cell wall structure and chemistry from the native wall to wall treated by thermal chemical pretreatment and enzymatic hydrolysis. While advancing our current understanding of plant cell wall recalcitrance and deconstruction, microscopic tools with improved spatial resolution will steadily enhance our fundamental understanding of cell wall function.
\end{abstract}

Keywords: Plant cell wall, Cell wall imaging, Biomass recalcitrance, Bioenergy, Lignocellulosic biomass, Stimulated Raman scattering, Atomic force microscopy, Fluorescence, Fluorescence lifetime imaging microscopy

\section{Background}

In our continuing endeavor toward producing renewable fuels and chemicals from plant biomass [1,2], considerable effort has been devoted to genetically optimizing the amount, chemical composition, and basic structure of plant cell walls $[3,4]$; as well as searching for better pretreatment and degradation methods $[5,6]$ to efficiently fragment biomass and produce fermentable sugars. No matter which direction is taken, these approaches break down the natural resistance of plant cell walls against deconstruction $[1,7,8]$. Cell wall chemistry and molecular architecture have already been proven to play a key role in the recalcitrance of energy plant cell walls [9]. At molecular level, the composition of cell wall layers,

\footnotetext{
*Correspondence: Yining.Zeng@nrel.gov

1 Biosciences Center, National Renewable Energy Laboratory, Golden, CO 80401, USA

Full list of author information is available at the end of the article
}

especially the distribution and migration of lignin during pretreatment, significantly impacts the local enzyme accessibility to cellulose [10-12]. A detailed understanding of the structural organization of cell wall chemistry at the microscopic and molecular scales is required in the search for effective biological and biochemical deconstruction of energy plant cell walls. By gaining critical insight into the fundamentals of wall structure, biomechanics, and reactions to stress and developmental modulations, microscopy helps us understand the manifestation of macroscopic observations. Novel imaging technologies provide unprecedented opportunities to probe the chemical functionality of wall polymers in the native state and during conversion to fermentable sugars. In this review, we provide a brief overview of recent progress by microscopy approaches toward understanding the chemical functionality of the plant cell wall, as well as its changes when subject to pretreatment and enzymatic degradation. 


\section{Wall polymers of plant and their chemical functionalities}

Energy plants, including grasses such as maize [13], sorghum (Sorghum spp.) [14], switchgrass (cultivars of Panicum virgatum) [15], miscanthus (Miscanthus and other Miscanthus spp.) [16], and energy cane (Saccharum complex) [17] and trees such as poplar (Populus trichocarpa, and other Populus spp.) [18], willow (Salix spp.) [19], pine (Pinus spp.) [20], and eucalyptus (Eucalyptus spp.) [21], are sustainable and renewable feedstocks for biofuels production. The cell wall comprises most of the plant's dry weight and is composed primarily of three polymer components: cellulose, hemicellulose, and lignin. Dry plant in general contains 40 to $50 \%$ of cellulose, 15 to $25 \%$ hemicelluloses, 20 to $25 \%$ lignin, and 5 to $10 \%$ other components.

Polysaccharides are the principal components of plant cell walls and comprise their structural framework. Consisting of $(1 \rightarrow 4)$ - $\beta$-glucan units, cellulose is the most abundant plant cell wall polysaccharide [22]. Cellulose is synthesized by cellulose synthases at the plasma membrane by building $\beta$-glucan chains from UDP-glucose [23]. The cellulose microfibril grows from the non-reducing end by cellulose synthesis complex and is soon packed into an insoluble crystalline structure at the growing cell wall [24]. Cellulose is utilized to produce bioethanol and other chemicals by liberating glucose through chemical and biologically breakdown achieved by cellulolytic enzymes [25, 26] and fermentative microorganisms [27, 28 ]. Enzymatic hydrolysis of insoluble cellulose usually requires endoglucanases, exoglucanases (cellobiohydrolases), and $\beta$-glucosidases working in synergy $[29,30]$. The heterogeneity [31] and insolubility [32] of the cellulose microfibril can produce a challenge for cellulolytic enzymes.

Hemicelluloses are the second most abundant heterogeneous polymers containing various monosaccharide subunits to form xylans, xyloglucan, mannans and glucomannans, and others $[3,33]$. In plants, hemicelluloses are synthesized in the Golgi membranes [34]. It is also known that through covalent and non-covalent interactions with cellulose and lignin, hemicellulose contributes to strengthening the cell wall [35]. Unlike cellulose and lignin, hemicelluloses can be readily solubilized when treated by different temperatures and concentrations of alkali, acid, and other chemicals. Dilute sulfuric acid hydrolysis, for example, has proven to be a favorable process for solubilizing hemicelluloses and converting them into sugars [36, 37]. Besides chemical hydrolysis, enzymes (i.e., hemicellulases) are also used for hydrolyzing hemicelluloses [38].

Lignin and hemicelluloses are polymers matrixed around cellulose microfibrils and they are believed to be the main contributors to biomass recalcitrance $[39,40]$. Lignin accounts for 20 to $35 \%$ of the dry weight of cell walls. In living plants, lignin is essential for the cell wall structural integrity by imparting stiffness and strength to the stem and root of the plant [41]. Lignin also contributes to the water proofing of conductive elements within the xylem tissue, which facilitates transport of water and solutes through the vascular system [42]. This waterproofing function helps protect plants against the pathogens, as well as the overall "biochemical invasion." Lignin is a heteropolymer that normally contains three types of monomer units, syringyl (S), guaiacyl (G), and p-hydroxyphenyl $(\mathrm{H})$ [43]. Recently, a new type of lignin polymer, caffeyl alcohol (C) lignin, has been proposed to be a potential candidate for renewable carbon fiber production [44]. Lignification is the final stages of cell differentiation in lignifying tissues. During lignification, lignin is deposited through free radical reactions within the carbohydrate matrix of the cell wall, infilling the inter-lamellar space by forming covalent bonds to the surrounding non-cellulosic carbohydrates [45]. As a result, lignin polymers present a chemically and structurally complex macromolecule that occurs predominantly in the xylem, tracheids, vessels, and fiber cell walls of land plants.

Cellulose, hemicellulose, and lignin entangle to form a complex matrix. One challenge for efficient utilization of cellulose, hemicellulose, and even lignin is to separate and depolymerize certain polymers without inadvertently impacting the others. Biomass recalcitrance is a collective phenomenon arising from both chemical and structural aspects of plants and cell wall across a wide range of length scales. At the molecular level, the extent of cellulose crystallinity [46] and the crosslinks between cellulose $[47,48]$, hemicellulose $[49,50]$, and lignin $[51$, 52] limit the penetration of enzymes/microbes to cellulose. At the structure level, the amount and location of lignin, the cell wall thickness, wall lamina, chemical composition, and porosity contribute heavily to recalcitrance. These factors vary by type of biomass and type of pretreatment. Therefore, there is a high demand for microscopic imaging tools.

\section{Imaging techniques for visualizing wall features}

Numerous imaging techniques have been employed to investigate the content, concentration, and distribution of the biopolymer components within the plant cell wall. Traditional optical light microscopies, such as bright/ dark field microscopy [53] and polarized light microscopy [54], and both transmission electron microscopy [55] and scanning electron microscopy [56] have been used to visualize plant cell wall morphologies. To probe with chemical specificity, the autofluorescence of the lignin polymer is traditionally adopted to image lignin 
distribution in the cell wall [57]. By using cytochemical staining and other labeling techniques, imaging the distribution of different carbohydrates is achieved [58, 59]. Even with limited chemical specificity, microscopic imaging of cell wall polymers has revealed heterogeneity in their distribution among different tissues, cells types, and locations on wall [60-62]. Non-deconstructive and noninvasive imaging techniques that are widely used in medical applications have also been applied for plant tissue imaging. Nuclear magnetic resonance imaging (MRI) has been used to image water distribution in plant tissue [63]. Positron emission tomography (PET) has been used to image ${ }^{11} \mathrm{C},{ }^{13} \mathrm{~N},{ }^{15} \mathrm{O}$, and ${ }^{18} \mathrm{~F}$ isotopes in plant tissue [64]. $\mathrm{X}$-ray computed tomography $(\mathrm{CT})$ have also been applied to plant to produce 3D volumetric radiographic data [65]. Complementary to the above-mentioned in vivo imaging techniques (i.e., optical microscopy, MRI, PET, CT), mass spectrometry-based ex vivo imaging techniques (such as secondary-ion mass spectrometry, matrix-assisted laser desorption ionization) provide wide spectrum of chemical identity by harvesting appropriate samples from plant tissue [66]. For example, 3D time-of-flight secondary-ion mass spectrometry has been applied to image cellulose and lignin in plant cell wall [67]. More complex than bulk analysis, the rich information from microscopic imaging allows for more powerful analysis and quantitation to understand the chemical functionality of plant cell wall and its role in biomass conversion.

To precisely localize polymers in cell wall, recent endeavors have been devoted to improving chemical specificity and high spatial resolution. Non-destructive and label-free methods are capable of providing tissue/ cell type-specific, compositional and structural information in air or under a fluid. Lignin's autofluorescence can be used in fluorescence microscopy to image lignin directly. In addition to fluorescence emission intensity, fluorescence lifetime imaging microscopy (FLIM) also resolves lignin's autofluorescence decay lifetime [68]. Compared to other fluorescence microscopies, such as scanning confocal microscopy or total internal reflection fluorescence (TIRF) microscopy, each pixel in a FLIM image contains the fluorescence decay rate information in addition to fluorescence emission intensity, thus providing an extra dimension of measurement $[69,70]$. Besides fluorescence, lignin and non-fluorescent carbohydrates can also be imaged by chemical imaging microscopic techniques taking advantage of Raman vibrational fingerprints associated with their unique chemical structures [71, 72]. Chemical imaging of plant cell walls is now more efficiently performed by non-linear coherent Raman microscopies [73], such as coherent anti-Stokes Raman scattering (CARS) microscopy [74, 75] and stimulated Raman scattering (SRS) microscopy $[74,76]$. The coherent Raman signal generated by these non-linear processes is so much higher than traditional confocal Raman that a $2048 \times 2048$ pixel resolution image can be obtained in less a few min [77]. Both of these non-linear coherent Raman microscopies have provided chemical mapping of cellulose [10, 77], lignin [74, 75, 77], and xylan [78] based on their unique vibrational frequencies. Considering that the spatial resolution of traditional optical microscopy is restricted by diffraction (best $<300 \mathrm{~nm}$ ) [69], atomic force microscopy (AFM) is an ideal tool to study the topographic and physical property of cell walls at nanometer scale and in its native state with minimum sample preparation (no fixation, freezing, dehydration, or metal coating) [79].

\section{Plant cell wall architecture}

The physicochemical properties of plant cell walls are determined not only by the chemical and physical properties of the individual cell wall polymers, but also by the spatial organization and interactions among them [80, 81]. Cell wall architecture plays a key role in determining recalcitrance. The plant cell wall has a multi-composite structure, consisting of several layers formed at different stages during cell growth and differentiation. The primary wall (PW), largely composed of cellulose, pectin, and hemicellulose, is formed first during plant cell growth stage [82]. While differentiating during growth, cells are expanded and elongated. Once the cell reaches its final size, the thickened secondary wall (SW) layers, accounting for most of biomass, are formed by deposit of wall substances onto the inside of the PW [83]. The parenchyma-type SWs (pSW) are thickened walls in parenchyma and collenchyma, which are normally in living cells; the sclerenchyma-type SWs (sSW) are secondarily thickened walls in highly differentiated cells, such as tracheary elements and fibers, which are elongated and dead cells [84-86]. Cell wall chemical composition varies dramatically in different cell types, different tissues, and different plant species. PW are non-lignified and they exist in some cells. Thickened SW are usually lignified and consist of multilayered structures from outside to inside: highly lignified compound middle lamellae (CML) containing middle lamellae and the primary wall, a thin S1 layer, a thick less-lignified middle layer S2, a thin inner layer S3, and a warty layer formed by lignin precursors. These lignified SWs account for the majority of the mass of plant biomass. The last stage of wall thickening also produces, inside the S3 layer, a warty layer which is resistant to a wide range of reagents [87].

Cellulose microfibrils form the scaffold of cell walls. The S1 layer is usually 300 to $400 \mathrm{~nm}$ thick and is composed of several lamellae of altered cellulose microfibrils with an orientation along the long axis of the cell [88, 

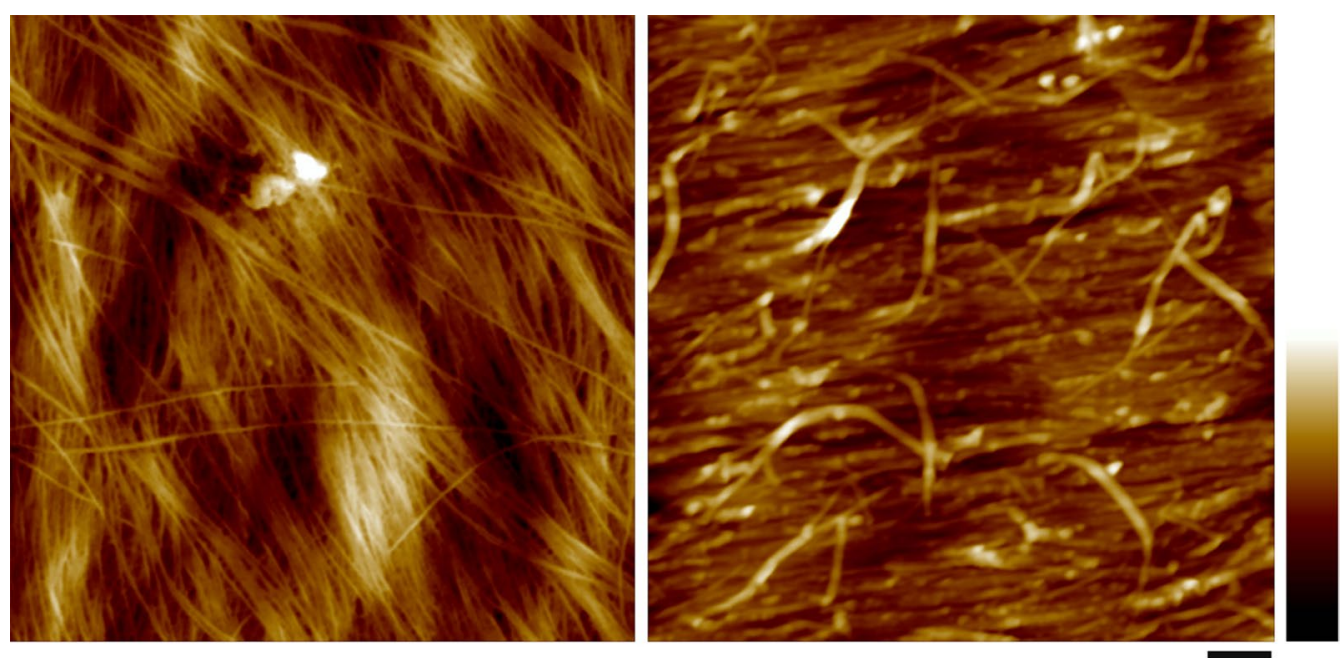

Fig. 1 Atomic force micrograph of primary and secondary cell wall structure from maize. Left, cellulose microfibrils form varying sizes of bundles in PW. Right, cellulose microfibrils are heavily coated by matrix polymers in the S2 layer of SW. The image was taken from the cutting face of a vascular fiber cell from maize (reprinted from [10] with permission). Scale bar $=100 \mathrm{~nm}$, color bar $=30 \mathrm{~nm}$

89]. The $\mathrm{S} 2$ contains most of the cell wall cellulose and has a high content of parallel cellulose microfibrils [81]. AFM provides many useful details about cell wall cellulose microfibril organization at or near-physiological conditions [90-92]. At molecular level, cellulose forms rigid microfibrils which interact directly or indirectly with amorphous matrix polymers to form the composite cell wall lamellae. The cellulose microfibrils are often observed in AFM as bundles in the PWs that are composed of a number of cellulose elementary fibrils (CEFs) (Fig. 1). Although the size and cross-sectional shape of the CEF has not been determined, there is a general agreement about cellulose biosynthesis in vivo-where at least three cellulose synthase (CESA) isoforms are required to assemble a cellulose synthase complex (CSC) in the plasma membrane and together functions to synthesize the CEF [93, 94]. An 18-mer CESA complex has been proposed recently based on electron microscopy (EM) and freeze fracture techniques and computer simulation [95]. Assuming that all CESAs in the CSC are active and each synthesizes one glucan chain, it would result in an 18-chain microfibril. Other CEF models containing 36, 24 chains with hexagonal, square, or irregular cross-sectional shapes have also been proposed [96-101], further investigation in high spatial resolution imaging, particularly AFM is required to directly visualize the native structure of cellulose.

Lignin has been conveniently imaged label-free by using stimulated Raman microscopy taking advantage of lignin's strong Raman band at $1600 \mathrm{~cm}^{-1}[10,11,74$, 75]. As shown in Fig. 2, the various lignin concentrations in muro are the result of unique stage of lignin synthesis

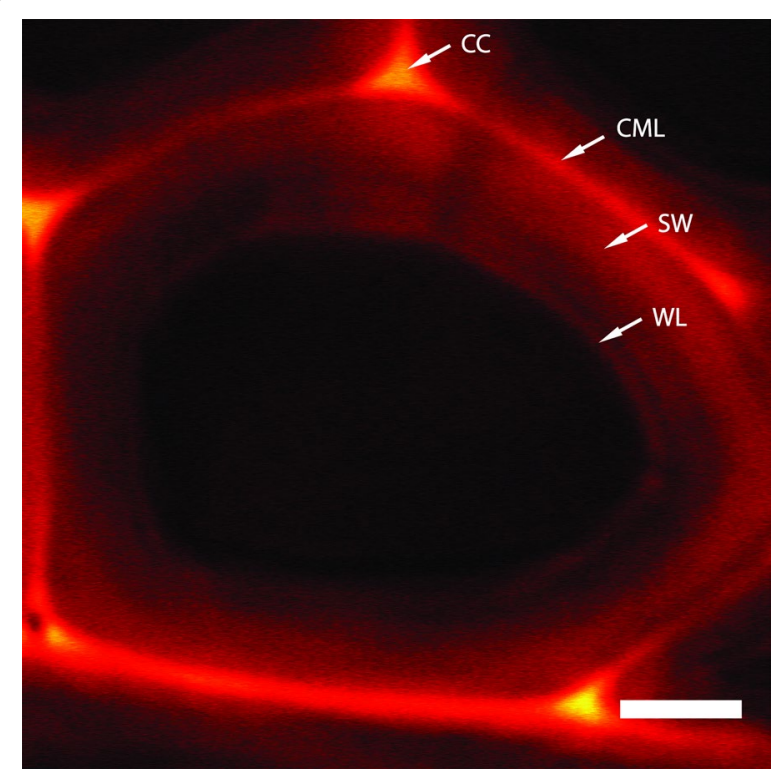

Fig. 2 Lignin distribution in poplar tracheid cell wall imaged by stimulated Raman scattering microscopy by lignin's aryl ring stretch at $1600 \mathrm{~cm}^{-1}$ (reprinted from [11] with permission). Lignin is unevenly distributed in cell wall layers. Highest lignin content is shown in the cell corner (CC), compound middle lamella (CML), and the warty layer (WL). Secondary wall (SW) has a lignin distribution gradient from outside (high) to inner side (low). Scale bar $=5 \mu \mathrm{m}$

during plant development. Lignification is the last stage of cell division, expansion, and elongation before cell death. In plants, lignin is synthesized through a radical polymerization process involving oxidative coupling of 4-hydrophenylpropanoids. This process can be either 
biologically programmed or triggered by environmental factors, such as stress conditions. Lignin monomers are produced inside cell membrane and then delivered to cell wall via mechanisms that are not completely understood. Lignification starts from the cell corner, accumulates in CML, and extends into PW, S1, S2, and S3, resulting in the lignin concentration gradient from high to low in these layers [11]. As shown in Fig. 2, the cell corner and CML have the highest lignin content. The adjacently lignified PW and S1 also have relatively high lignin concentrations. Moreover, the S2 and S3 are away from the lignification initialization sites and have less lignin content. The warty layer next to S3 is composed of highly cross-linked lignin precursors that are formed while the cell is in the final stage of lignification and death [11]. In biomass, the sSWs have fully lignified CML and warty layers; the pSWs are partially lignified and do not contain the S3 and the warty layer.
Like lignin, cellulose has also been chemical imaged by its Raman band at $1100 \mathrm{~cm}^{-1}[71,72]$. However, chemical imaging of hemicellulose has been challenging. Due to the complex nature of plant materials, especially the chemical and structural similarities between hemicellulose (largely xylan) and cellulose, the utility of specific Raman vibrational modes that are unique to xylan has been debated. In a recent attempt to probe xylan-specific Raman bands, Zeng and coworkers [78] reported a novel approach based on combining spectroscopic analysis and chemical/enzymatic xylan removal. The authors identified several Raman peaks that are associated with xylan content in cell walls to be used for label-free in situ imaging of xylan. By using the above xylan signature Raman bands, along with those of lignin and cellulose, the 3D distribution of lignin, cellulose, and xylan (hemicellulose) in corn stover cell wall can be reconstructed through SRS section scanning (Fig. 3). Based on the 3D distributions, further material statistical analysis for their spatial

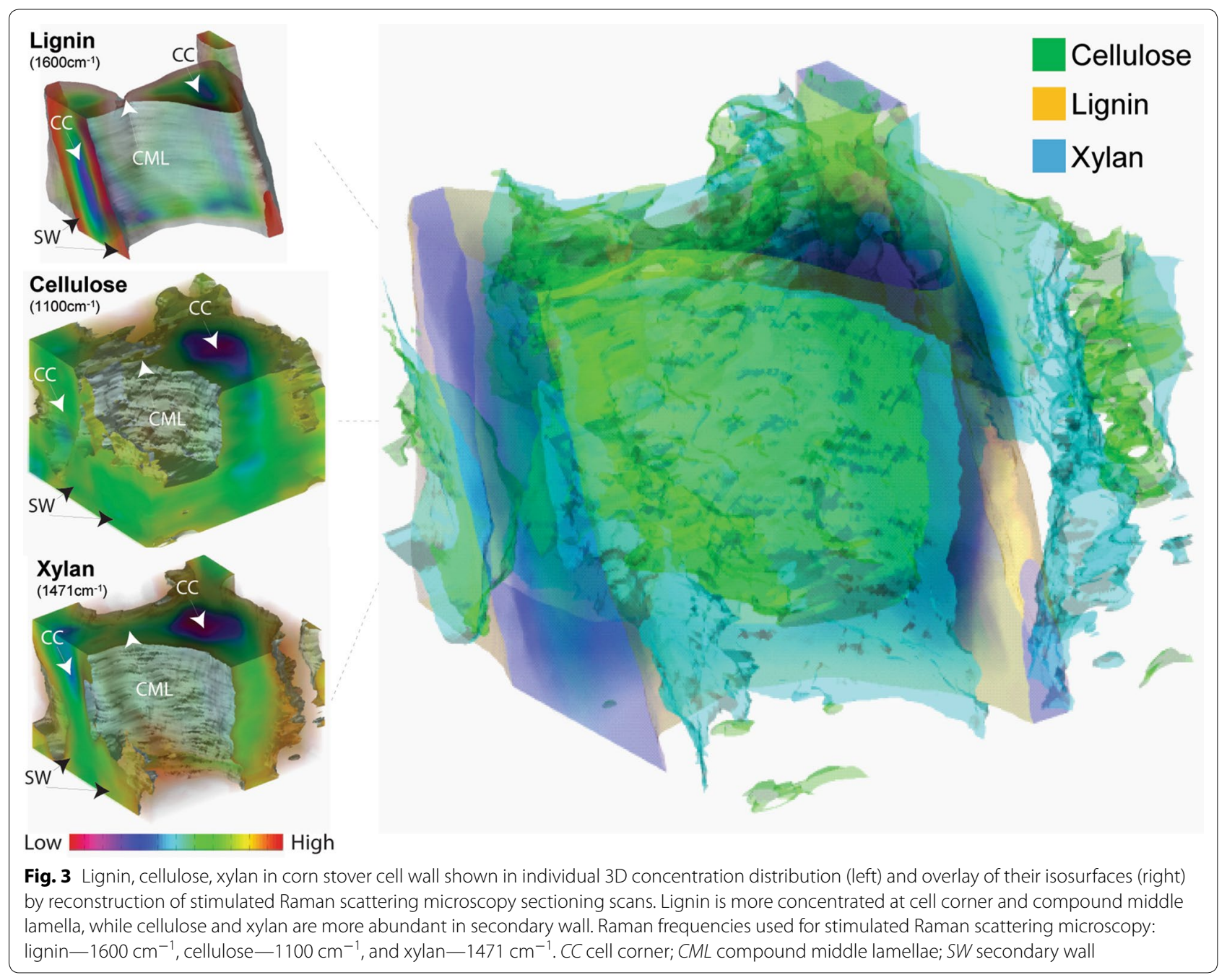


distribution, such as volume, porosity, density, can be obtained.

\section{Wall change during pretreatment}

Plant cell walls have evolved to resist natural breakdown from microbial, chemical, and mechanical challenges. Biomass recalcitrance is collectively determined by many factors, such as the content of cellulose/lignin/hemicellulose, the acetylation [102], methylation [103], heteropolysaccharide deposition [104], inter-chain covalent bonding [105], H-bonding [106], van der Waals interaction [107], and finally pore size/density [108]. Note that to overcome recalcitrance, feedstocks in biochemical refinery will be routinely treated with acid and alkali at elevated temperature/pressure to expose useable polysaccharides to enzymes.

For decades, lignin has been viewed as the primarily contributor for biomass recalcitrance [11, 109]. In biorefinery, the amount and distribution of lignin throughout the cell wall determines the processing and eventual commercial utilization of energy plants. Since in the living plant lignin functions to provide cell wall with waterproofing, mechanical support, and resistance to breakdown, the chemical and structural characters of lignin are major barriers to deconstruction and utilization of lignocellulosic biomass. Therefore, one of the major strategies of biomass pretreatment has been aimed to remove lignin from the feedstock in order to enhance the accessibility of the polysaccharides to degradative cellulolytic enzymes and microbes. More recently however, a new view of lignin has emerged where it is not viewed purely as a barrier to polysaccharides utilization, but as a potentially useful and valuable component of biomass serving its own application for renewable chemicals [110]. Nevertheless, challenges of incorporating lignin conversion into the biorefinery scheme remain depolymerizing lignin and removing it from the cell wall without inadvertently generating any refractory form to processing.

As mentioned above, the SW constitutes most of the biomass dry weight and is the target for pretreatment. In the SW, lignin forms hydrophobic networks and is covalently bonded to hemicellulose. Layers of cellulose-hemicellulose and hemicellulose-lignin form a sandwich-like lamellae structure. In order to access these polysaccharides, specifically lignin in S2, must be removed. Lignin covalently binds to carbohydrates through benzyl ether bond [111], benzyl ester bond [112], phenyl glycoside bond [113], and acetal type bond [114] to form lignincarbohydrate networks, connecting lignin firmly to the carbohydrate surrounding. Chemical cleavage of aromatic rings of lignin monomers, linkages between lignin units, ester or ether bonds between lignin and hemicellulose could all release lignin from polysaccharide network.

Pretreatments, such as dilute acid treatment at high temperature, can hydrolyze glycosyl bonds in hemicelluloses [115] so that lignin-carbohydrate complex (LCC) are formed and redeposited on the biomass surface as droplets, thus exposing cellulose. Some other pretreatment methods directly remove lignin. Pretreatments utilizing alkali, or other chemistries that directly hydrolyze the $\beta-O-4$ linkages in lignin, depolymerize the lignin polymer sufficiently so it can be efficiently extracted from the cell wall [116]. In order to remove lignin in the SW, the condensed lignin layers must be first fragmented, which may require the combined effects of mechanical, temperature, and chemistry, namely high severity treatment [11]. In plant cell wall, the inner face of the pSWs is non-lignified and already accessible, whereas in the sSWs, the $\mathrm{S} 2$ layer is sealed by CML and warty layer. By using GFP-tagged CBMs and enzymes, Ding and coworkers [10] visualized the accessibility of untreated cell walls. It was shown that the binding of CBMs and enzymes exhibits a strong negative correlation with lignin content in the cell wall layers. As shown in Fig. 4, CBMs and enzymes bind more to non-lignified PWs, less to pSWs, and negligibly to the condensed lignin in the "warty layer" in sSWs. Lignin removal enhanced overall binding of all CBMs and enzymes to lignified pSWs and sSWs. It was observed that accessibility of pSWs and sSWs to enzymes was enhanced more than that to CBMs, which could be explained by the increased accessibility of hemicelluloses to enzymes following lignin removal.

Pretreatment strategies may be adapted to different biomass feedstocks [117]. For example, dilute acid is sufficient for grassy feedstocks, because there are enough pSWs to allow acid penetration from the inner side of their walls. The same pretreatment condition may not work well for woody biomass, because wood chips are composed of predominately sSWs, which require much higher severity or different pretreatment methods that combine physical (milling or steam explosion) and chemical (delignification) processes.

It has now been widely accepted that pretreatment strategies need not specifically target lignin removal, but relocalize the lignin from its native context of close association with cellulose microfibrils [118]. One such example is thermochemical pretreatments that reach temperatures above the glass phase transition of lignin to cause effective physical and chemical perturbation to lignin network. As a result, the coalescence of lignin within cell walls and migration out of biomass during thermochemical pretreatments, accompanied by some subsequent re-deposition of lignin globules (lignincarbohydrate complex, LCC) on cell wall surfaces has 


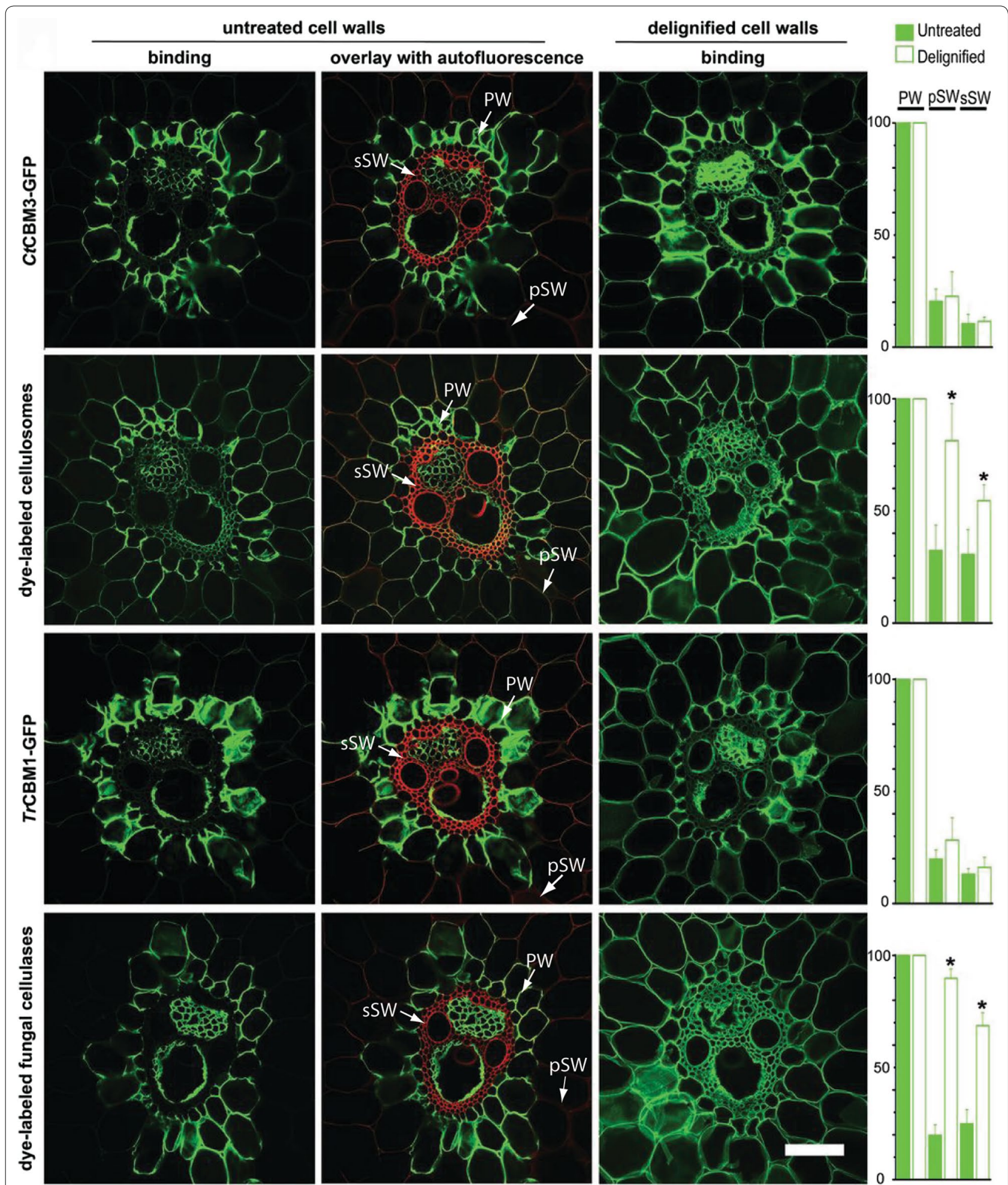

Fig. 4 Confocal laser scanning microscopy of cell walls in transverse section of vascular bundle area when exposed to GFP-CBMs (reprinted from [10] with permission). CBMs specifically recognize cellulose, which is highly accessible in PWs, less accessible in pSWs, and non-accessible in sSWs. Lignin's autofluorescence (red) and overlay images highlight the negative correlation between binding and lignin distribution. Delignification significantly increases cell wall accessibility to enzymes (paired $t$ test, ${ }^{*} P<0.05$ ). Histograms showing relative fluorescence intensity are expressed as percentages of fluorescence compared with the intensity of the labeled PW, which is designated as 100\%. Delignified pSWs in the rind area were imaged in higher magnification. Scale bars $=50 \mu \mathrm{m}$ 
been observed [119]. Regardless of which pretreatment applied, one of their crucial attributes of all pretreatment strategies is the removal or relocalization of lignin to improve the accessibility of the carbohydrate in cell walls.

Fluorescence lifetime imaging microscopy (FLIM) has been applied to track lignin's fate in poplar during maleic acid pretreatment [76], a pretreatment previously showed lower sugar degradation than dilute acid pretreatment [120-122]. Zeng and coworkers found that the decay lifetime of lignin's autofluorescence is correlated to the degree of condensation of lignin in the wall and the LCC produced by the maleic acid pretreatment. This lifetime is shorter for dense lignin and longer for loose lignin. In the FLIM images shown in Fig. 5, the dense lignin in the cell corner and compound middle lamella of poplar cell wall marked by shorter lifetime is clearly contrasted with the less dense lignin in the secondary wall shown in the longer lifetime case. Pretreatment produces LCC droplets containing various concentrations of lignin, as indicated by droplets displaying a wide range of fluorescence lifetimes in the FLIM images. Moreover, interesting evidence for lignin biosynthesis is obtained from FLIM images. In plants, I-lignification occurs during the early stage of secondary cell wall thickening at the cell corners, where a relatively high concentration of lignin monomers and peroxidases fill in an open space between cellulose microfibrils [123, 124]. Lignin is formed in the space and adhered between neighboring cells. I-lignification produces mostly dense lignin at the cell corner as confirmed by the short fluorescence lifetime observed at the cell corner. In compound middle lamella (containing no cellulose) and primary cell wall (containing mostly cellulose macrofibril), lignin appears to have slightly longer fluorescence lifetimes. In general, the cell corner and compound middle lamella contain dense lignin produced by I-lignification as evidenced by the relatively short fluorescence lifetime in FLIM images. Compared to I-lignification, S-lignification starts after the development of secondary cell wall. During S-lignification, lignin precursors permeate into the cellulose microfibrils framework in secondary cell wall producing relatively smaller amounts of lignin associated with large amounts of cell wall hemicellulose [124]. Lignin in SW produced by S-lignification is the less concentrated "loosely packed," which is also identified by the longer fluorescence lifetime in FLIM images.

Along with lignin removal, depending on biomass and pretreatment conditions, the depolymerization of hemicelluloses, physical separation of cell wall lamella, and creating porosity also contribute to enhance biomass accessibility. Enlarging the spaces among the cellulose microfibrils and creating pores are efficient to cellulase accessibility. AFM has been used to visualize enzymatic hydrolysis of isolated cellulose crystals $[125,126]$ and plant cell walls [10] in real-time (Fig. 6). It has been demonstrated that cellulases bind to and hydrolyze the hydrophobic faces of cellulose crystal [125, 126], which consequently result in "traffic-jam" in large crystals, while in the case of plant cell walls, the CEF is small, the enzyme accessibility to the substrate is the main ratelimiting factor that affects the efficiency of enzymatic hydrolysis [10]. In untreated biomass, the SWs are the major material of plant biomass, which is protected by lignin. Current cellulase mixture is not efficient in depolymerizing lignin, which physically impedes the accessibility of carbohydrate-active enzymes to access to the polysaccharides in the cell walls [10]. Therefore pretreatment is necessary to either remove lignin, such as dilute acid, or delocalized lignin, such as AFEX, so that cell wall polysaccharides, i.e., cellulose and hemicelluloses, can be hydrolyzed effectively by enzymes.

\section{Wall change during microbial/enzymatic conversion}

Enzymatic digestibility of the cell walls is strongly negatively correlated to their lignin content [11, 109]. Even though non-lignified PWs are readily digested without pretreatment, the portion of non-lignified PWs in biomass is negligible. The non-lignified pSWs, such as pSWs collected in maize before reproductive growth, are also degradable, while the fully lignified sSWs in the same plant is not degradable [109]. When lignin in SW is selectively bleached (i.e., cellulose and hemicelluloses remain nearly unchanged), microscopic imaging of various types of cell walls during enzymatic digestion showed that all SWs are then found to be digestible at rates comparable to the PWs. Microscopic studies by Ding and coworkers found that in native cell walls, cellulosomes bind to the pSW innermost surface, the cell corners, and the plasmodesmata, whereas fungal cellulases penetrated into the $\mathrm{pSW}$ from the innermost surface. In these studies, non-specific binding of enzyme to native lignin was negligible [10].

The LCCs from pretreatment is also a factor affecting enzyme digestion. In the pretreated biomass, residual lignin normally forms LCC droplets or particles. Depending on pretreatment chemistry, lignin may or may not be chemically modified, and the composition of resulting LCCs may contain nearly pure lignin or significant amounts of polysaccharides-mainly hemicelluloses. Enzyme binding to the LCCs; therefore, relies on the relative content of polysaccharide and its morphological structure. For instance, in pretreatment in aqueous condition, such as dilute acid, the LCCs may form micellelike structures where the lignin is the hydrophobic core and polysaccharides are surface displayed and thus 


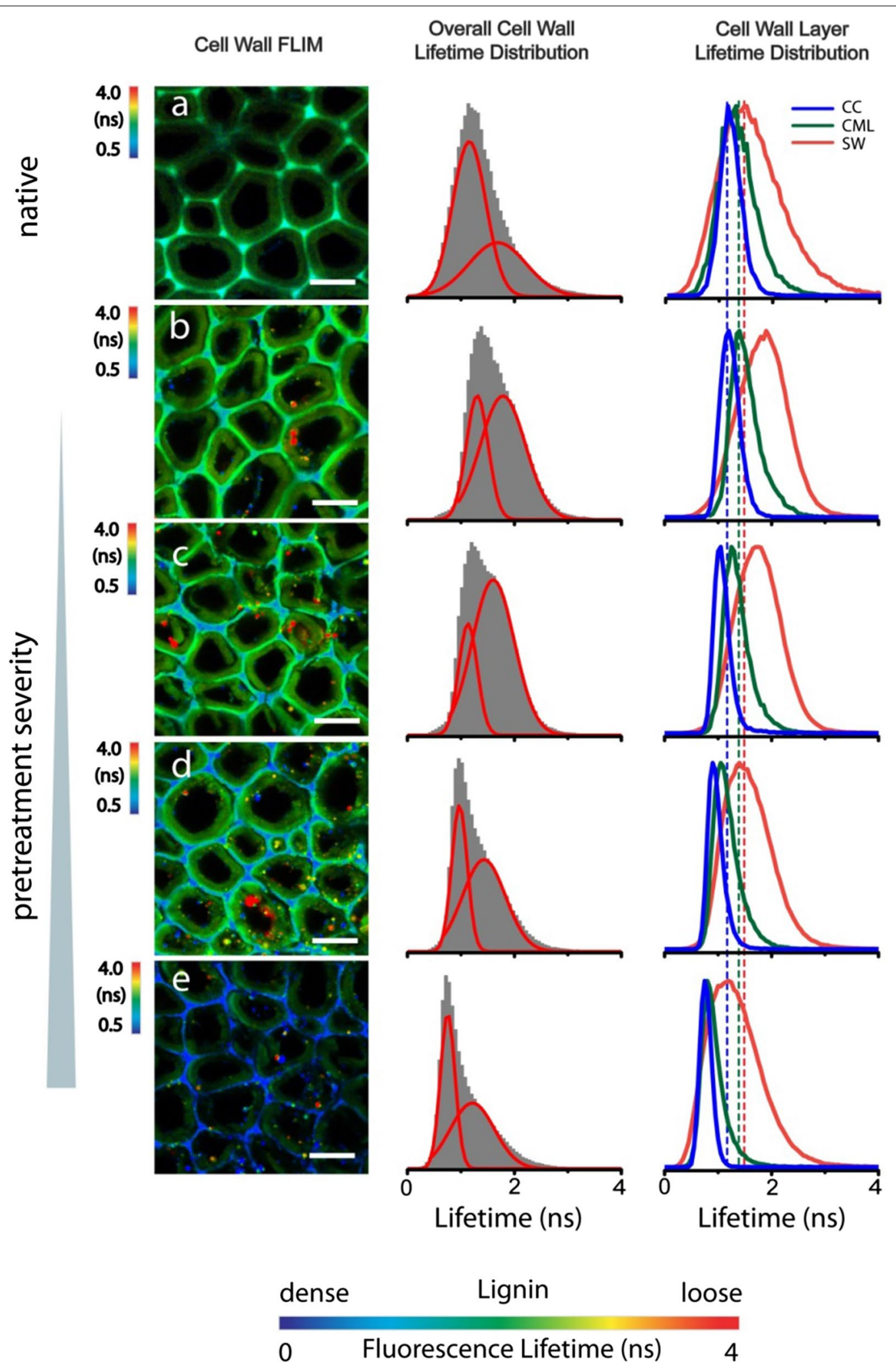

Fig. 5 (Left Column) FLIM images of lignin in poplar cell walls from lignin's autofluorescence (reprinted from [76] with permission). Comparison of untreated (a) and maleic acid-pretreated (b-e) poplar cell wall is shown. (Middle Column) Overall lignin fluorescence decay lifetime distribution across all the cell wall layers (gray). The two red curves are the two fitted Gaussian peaks by fitting the overall histogram, representing the dense and loose lignin in cell walls. (Right Column) Lignin fluorescence lifetime distributions within individual cell wall layer (CC cell corner; CML compound middle lamella; and SW secondary wall). Scale bar $=10 \mu \mathrm{m}$ 


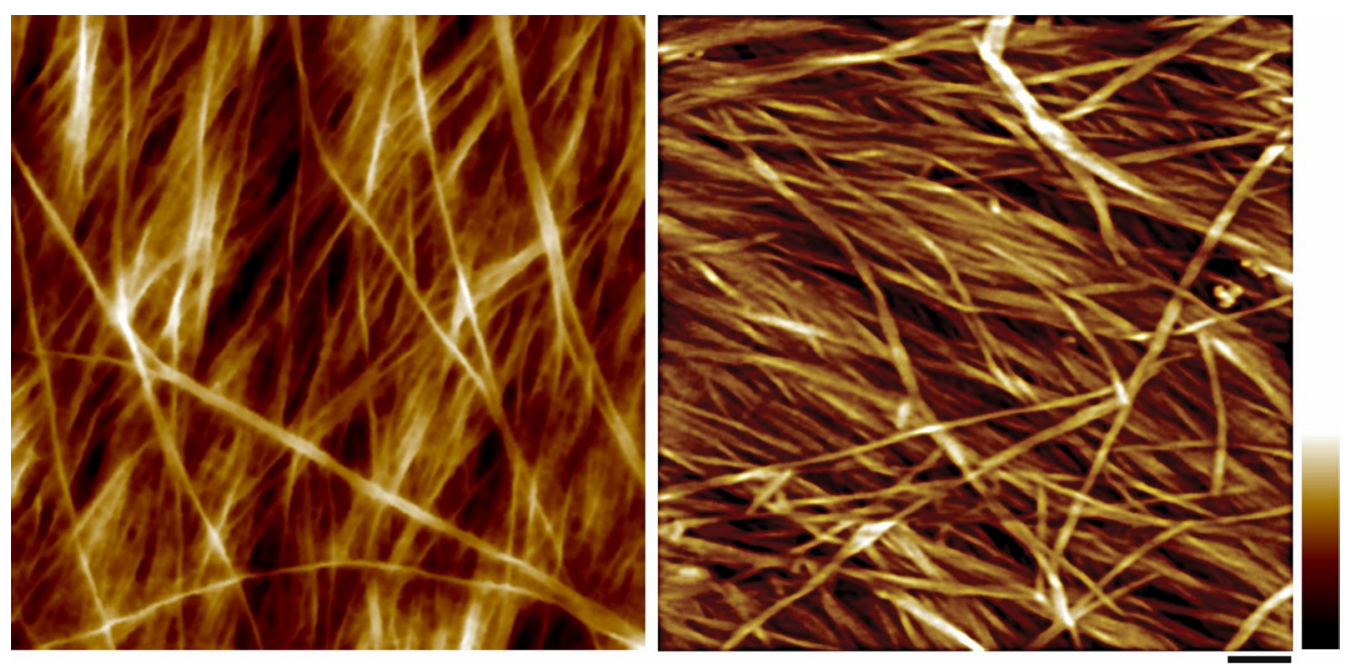

Fig. 6 Atomic force micrograph of primary and secondary cell wall after delignification. Left, PW of maize parenchyma. Right, SW of maize vascular fiber cell. Delignification condition: $0.1 \mathrm{~N} \mathrm{HCl}$ and $10 \% \mathrm{NaClO}_{2}$ at $1 \%(\mathrm{w} / \mathrm{v})$ biomass over night (reprinted from [10] with permission). Under this condition, lignin is nearly completely removed, and hemicelluloses are also partially removed. Scale bar $=50 \mathrm{~nm}$. Color bar $=20 \mathrm{~nm}$

attractive to non-productive binding of enzymes [127]. It has also been reported that lignin isolated from wood is more inhibitory to enzyme than that from herbaceous plant [128]; and lignin isolated from pretreated biomass, such as steam explosion, exhibited more inhibitory effect to enzymes than lignin isolated from non-pretreated raw biomass [129].

Although complete removal of lignin from biomass results in extremely digestible material as effective as corn starch, lignin removal must be performed at low temperature to avoid sugar degradation [130]. Microscopic studies showed that delignification of pretreated biomass with removal of most hemicellulose may result in significant reduction of enzyme digestibility [131], which could be attributed to the collapse and aggregation of the cellulose microfibril network [12], both of which reduce efficient enzyme penetration and rapid digestion. Corn stover delignified by acid chlorite at room temperature to retain cellulose and hemicellulose structure can be completely digested within $10 \mathrm{~h}$ at relative low loading of current commercially available cellulases [10]. Although ensemble solution measurement can only tell the difference in digestion rate, microscopic investigation discovered dramatically different mechanisms of cell wall digestion between cellulosomes and fungal cellulases
[10]. As shown in Fig. 7, cellulosomes digested the cell wall in two steps: first separated the walls from CML and then dissolved the fragmented cell wall segments. By contrast, fungal cellulases digested in a more uniform rate across the whole cell wall.

Real-time imaging of lignin degradation by acidic chlorite pretreatment [77] and cellulose digestion by enzymes [10] has been achieved by stimulated Raman scattering microscopy. More recently, the impact on xylan distribution in cell walls by xylanase digestion was shown by both 2- and 3-dimensional display [78] Zeng and coworkers used stimulated Raman scattering microscopy to image xylan, cellulose, and lignin following xylanase digestion (Fig. 8). Cell wall morphology and distribution of lignin, cellulose, and xylan in the same cell walls is compared before and after xylanase treatment. In contrast to lignin and cellulose Raman channels, dramatic concentration loss was observed for xylan. Importantly, besides significant reduction in concentration, xylan distribution in the cell walls was also altered by enzymatic digestion to take on "punctate type" morphology. Moreover, zoomed-in xylan images of two representative areas in the vascular bundle region showed significant xylan distribution changes due to the enzymatic digestion. 


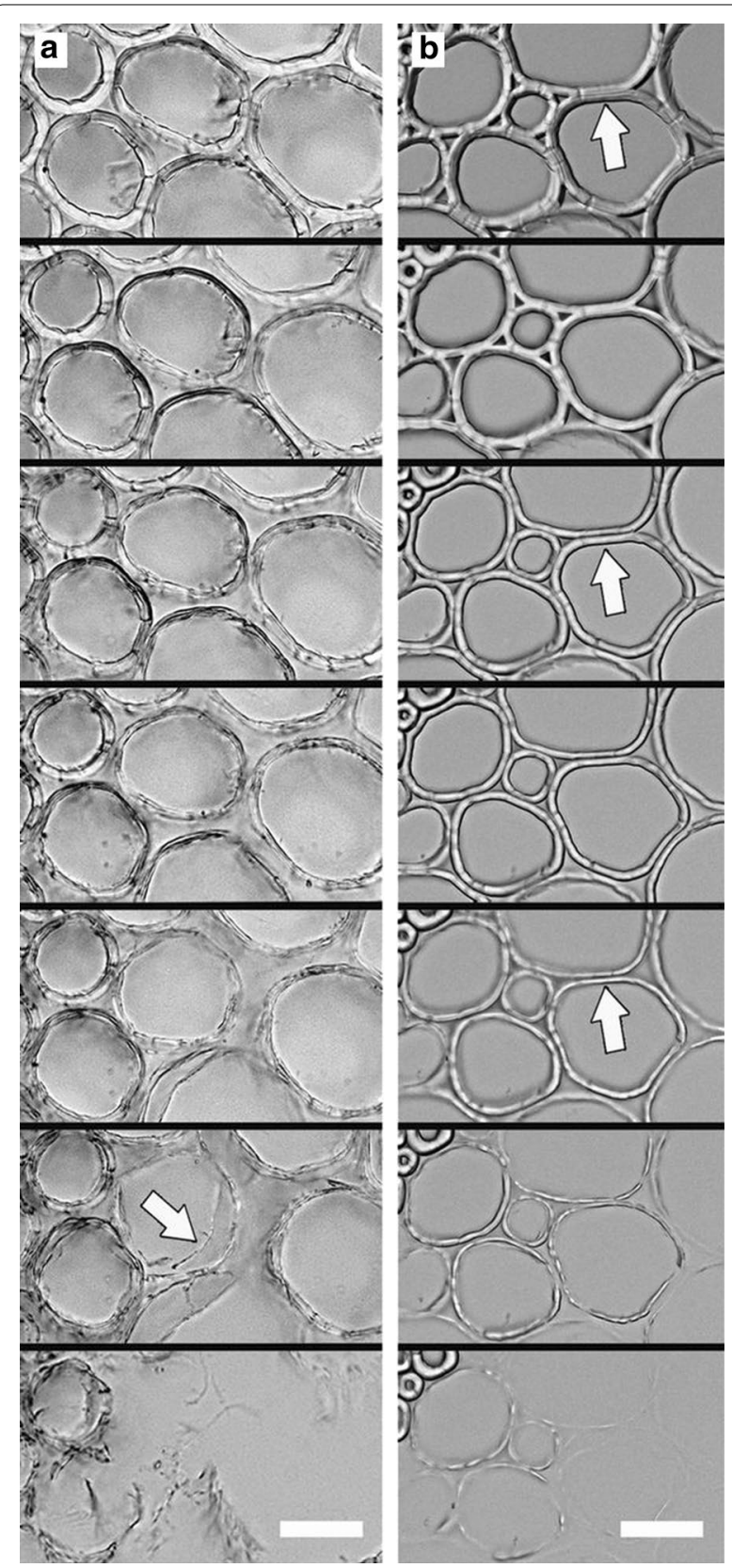

Fig. 7 Delignified pSWs imaged in real-time during digestion at room temperature (reprinted from [10] with permission). Bright-field light microscopy of a transverse section digested (a) by cellulosomes for 7 days, showing wall fragmentation (white arrow), and (b) by fungal cellulases for $10 \mathrm{~h}$, showing wall dissolving. White arrows in (b) indicate the wall's innermost side. Scale bars $=50 \mu \mathrm{m}$

\section{Conclusions and future perspective}

Correlative imaging through customized microscopies has been constructed to follow changes in the same plant tissue under near-physiological conditions or during actual pretreatment. High chemical and spatial resolutions have been achieved at tissue, cell wall, and molecular levels. We suggest that pretreatments should be developed to maximize lignin removal and maintain cellulose and hemicellulose intact. Energy plants with genetically modified lignins are especially promising because lignin extraction under mild conditions preserves polysaccharides, rendering them more readily digestible in the absence of lignin.

The major plant cell wall polymers and the interactions among them continue to be important topics in the design and utilization of energy plants. Interesting questions regarding plant cell wall polymers remain to be answered and imaging studies can contribute by addressing the following: How is lignin associated? How is hemicellulose assembled? Many aspects of microbial or enzymatic deconstruction of cell walls are also not well understood. For example, how do the large cellulosomal enzymes function to digest the diversity of substrate specificities found in cell walls? And what is the molecular organization of fungal cellulosomes?

The capability of label-free super-resolution imaging wall in three dimensions will be tremendously beneficial to unravel the organization of cell wall polymers. Superresolution microscopic techniques have broken the traditional 200 to $300 \mathrm{~nm}$ Abbe limit for optical microscopy. Today, fluorescence-based super-resolution microscopies routinely achieve resolution at length scale $\sim 10 \mathrm{~nm}$. However, the spatial resolution in most Raman microscopies is still constrained by the optical diffraction limit. Surface-enhanced and tip-enhanced Raman spectroscopies can provide improved resolution, but it is difficult to extract quantitative information from the signal. Moreover, the plasmonic materials needed for signal enhancement may adversely affect the sample. By engineering the point-spread function, attempts have been made to improve the spatial resolution of CARS [132, 133]. Based on the photoswitching concept of stimulated emission depletion already applied in the fluorescencebased super-resolution imaging techniques, a stimulated Raman imaging technique known as "femtosecond 

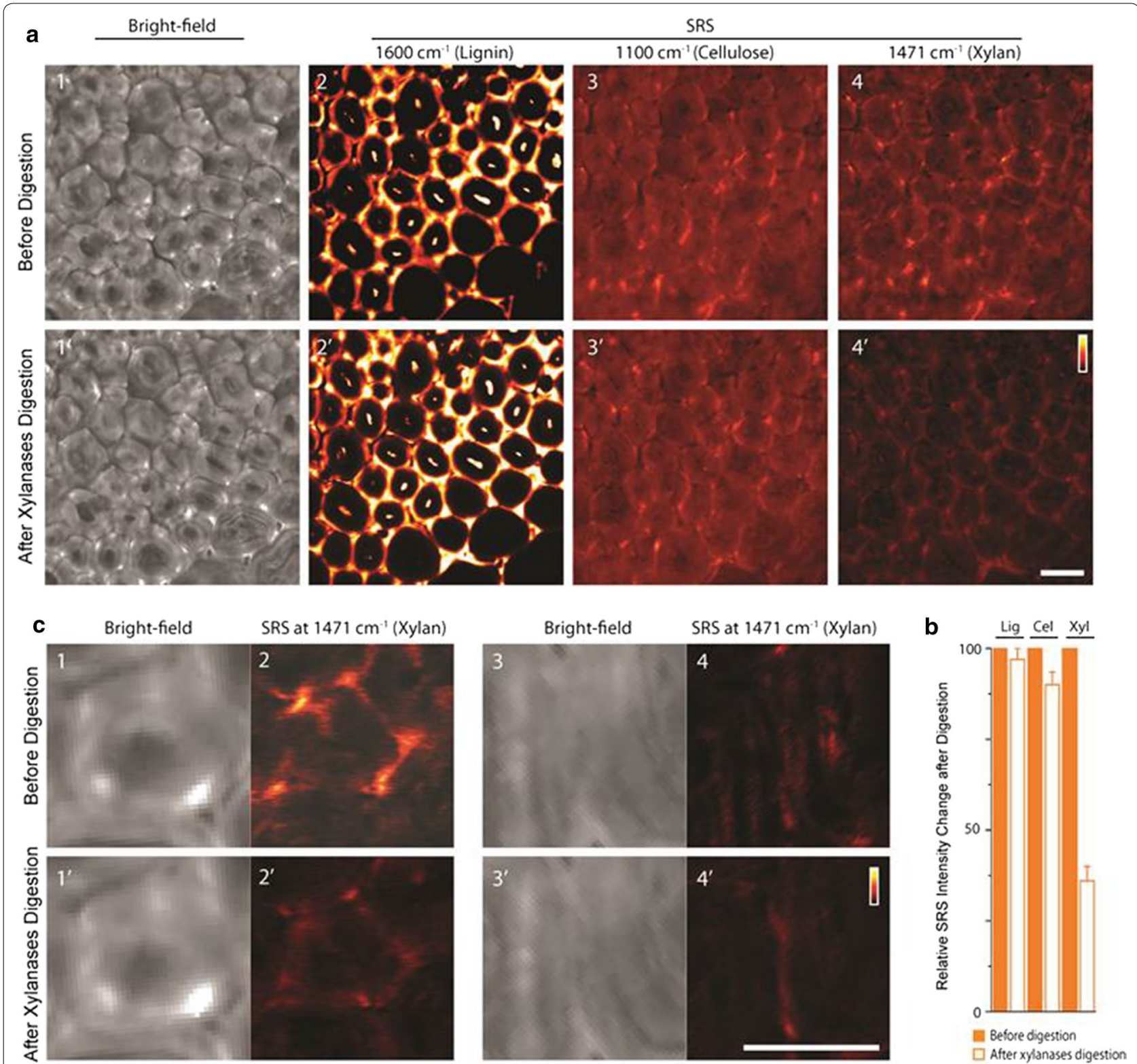

Fig. 8 In situ imaging by stimulated Raman scattering microscopy of lignin, cellulose, and xylan in corn stover cell walls before and after xylan digestion. (Reprinted from [78] with permission). a Comparison of bright-field cell wall morphology and concentration of lignin, cellulose, and xylan following xylanase digestion. b Comparison of overall amount change measured from SRS images (before xylan digestion $=100 \%)(\mathrm{Lig}$ lignin, Cel cellulose and $X y /$ xylan; error bars are from 5 repeat experiments). Lignin and cellulose are not affected, while xylan is significantly reduced due to xylanases digestion. c Zoom images of cell wall in two areas in vascular bundle region (C1-C4 before xylan digestion; and C1'-C $4^{\prime}$ after xylan digestion) show significant xylan distribution changes in the cell wall due to the heterogeneous enzymatic digestion. Raman frequencies used for SRS imaging: lignin $-1600 \mathrm{~cm}^{-1}$, cellulose $-1100 \mathrm{~cm}^{-1}$, and $x y l a n-1471 \mathrm{~cm}^{-1}$. Scale bar $=20 \mu \mathrm{m}$

stimulated Raman spectroscopy" has been reported to potentially achieve resolution $<50 \mathrm{~nm}[134]$.

\section{Abbreviations}

MRI: nuclear magnetic resonance imaging; PET: positron emission tomography; CT: X-ray computed tomography; FLIM: fluorescence lifetime imaging microscopy; TIRF: total internal reflection fluorescence; AFM: atomic force microscopy; PW: primary wall; SW: secondary wall; pSW: parenchyma-type
SWs; SSW: sclerenchyma-type SWs; CML: compound middle lamellae; CEFs: cellulose elementary fibrils; CESA: cellulose synthase; CSC: cellulose synthase complex; EM: electron microscopy; WL: warty layer; LCC: lignin-carbohydrate complex; CC: cell corner; CARS: coherent anti-Stokes Raman scattering; GFP: green fluorescent protein; CBM: carbohydrate-binding module.

\section{Authors' contributions}

YZ and S-YD wrote the manuscript. YZ, MEH, and S-YD edited the manuscript. All authors read and approved the final manuscript. 


\begin{abstract}
Author details
${ }^{1}$ Biosciences Center, National Renewable Energy Laboratory, Golden, CO 80401, USA. ${ }^{2}$ BioEnergy Science Center (BESC), Oak Ridge National Laboratory, PO Box 2008 MS6341, Oak Ridge, TN 37831, USA. ${ }^{3}$ Department of Plant Biology, Michigan State University, East Lansing, Ml 48824, USA.
\end{abstract}

\section{Competing interests}

The authors declare that they have no competing interests.

\section{Availability of supporting data}

Not applicable.

\section{Consent for publication}

Not applicable.

\section{Ethical approval and consent to participate \\ Not applicable.}

\section{Funding}

YZ and MEH acknowledge support from the BioEnergy Science Center (BESC), a DOE Bioenergy Research Center funded by the Office of Biological and Environmental Research (BER) in the DOE Office of Science. S-YD acknowledges support from the US Department of Energy (DOE) Great Lakes Bioenergy Research Center (DOE Biological and Environmental Research, the Office of Science DE-FC02-07ER64494).

\section{Publisher's Note}

Springer Nature remains neutral with regard to jurisdictional claims in published maps and institutional affiliations.

Received: 31 July 2017 Accepted: 2 November 2017

Published online: 30 November 2017

\section{References}

1. Himmel ME, Ding S-Y, Johnson DK, Adney WS, Nimlos MR, Brady JW, et al. Biomass recalcitrance: engineering plants and enzymes for biofuels production. Science. 2007;315(5813):804-7. https://doi.org/10.1126/ science.1137016.

2. Ragauskas AJ, Williams CK, Davison BH, Britovsek G, Cairney J, Eckert CA, et al. The path forward for biofuels and biomaterials. Science. 2006;311(5760):484-9.

3. Mohnen D. Pectin structure and biosynthesis. Curr Opin Plant Biol. 2008;11(3):266-77. https://doi.org/10.1016/j.pbi.2008.03.006.

4. McCann MC, Carpita NC. Designing the deconstruction of plant cell walls. Curr Opin Plant Biol. 2008;11(3):314-20. https://doi.org/10.1016/j. pbi.2008.04.001.

5. Wyman CE. Aqueous pretreatment of plant biomass for biological and chemical conversion to fuels and chemicals. Hoboken: Wiley; 2013.

6. Mosier N, Wyman C, Dale B, Elander R, Lee Y, Holtzapple M, et al. Features of promising technologies for pretreatment of lignocellulosic biomass. Bioresour Technol. 2005:96(6):673-86.

7. DeMartini JD, Pattathil S, Miller JS, Li H, Hahn MG, Wyman CE. Investigating plant cell wall components that affect biomass recalcitrance in poplar and switchgrass. Energy Environ Sci. 2013;6(3):898-909.

8. McCann MC, Carpita NC. Biomass recalcitrance: a multi-scale, multifactor and conversion-specific property. J Exp Bot. 2015;66(14):4109-18.

9. Himmel ME. Biomass recalcitrance: deconstructing the plant cell wall for bioenergy. Hoboken: Wiley-Blackwell; 2009.

10. Ding SY, Liu YS, Zeng YN, Himmel ME, Baker JO, Bayer EA. How does plant cell wall nanoscale architecture correlate with enzymatic digestibility? Science. 2012;338(6110):1055-60. https://doi.org/10.1126/ science.1227491.

11. Zeng Y, Zhao S, Yang S, Ding S-Y. Lignin plays a negative role in the biochemical process for producing lignocellulosic biofuels. Curr Opin Biotechnol. 2014;27:38-45. https://doi.org/10.1016/j.copbio.2013.09.008.

12. Chundawat SPS, Donohoe BS, da Costa Sousa L, Elder T, Agarwal UP, Lu F, et al. Multi-scale visualization and characterization of lignocellulosic plant cell wall deconstruction during thermochemical pretreatment. Energy Environ Sci. 2011;4(3):973-84. https://doi.org/10.1039/ c0ee00574f.

13. Ding SY, Himmel ME. Anatomy and ultrastructure of maize cell walls: an example of energy plants. In: Himmel ME, editor. Biomass recalcitrance: deconstructing the plant cell wall for bioenergy. Blackwell Publishing; 2008. pp 38-60.

14. Türe $S$, Uzun D, Türe IE. The potential use of sweet sorghum as a nonpolluting source of energy. Energy. 1997;22(1):17-9.

15. Schmer MR, Vogel KP, Mitchell RB, Perrin RK. Net energy of cellulosic ethanol from switchgrass. Proc Natl Acad Sci. 2008;105(2):464-9.

16. Lewandowski I, Clifton-Brown J, Scurlock J, Huisman W. Miscanthus: European experience with a novel energy crop. Biomass Bioenerg. 2000;19(4):209-27.

17. Matsuoka S, Kennedy AJ, dos Santos EGD, Tomazela AL, Rubio LCS. Energy cane: its concept, development, characteristics, and prospects. Adv Bot. 2014;2014:1-13.

18. Tuskan G, DiFazio S, Teichmann T. Poplar genomics is getting popular: the impact of the poplar genome project on tree research. Plant Biol. 2004;7(01):2-4.

19. Keoleian G, VolkT. Renewable energy from willow biomass crops: life cycle energy, environmental and economic performance. Crit Rev Plant Sci. 2005;24(5-1):385-406.

20. Lehtimäki J, Nurmi J. Energy wood harvesting productivity of three harvesting methods in first thinning of scots pine (Pinus sylvestris L.) Biomass Bioenerg. 2011;35(8):3383-8.

21. Gonzalez R, Treasure T, Wright J, Saloni D, Phillips R, Abt R, et al. Exploring the potential of eucalyptus for energy production in the Southern United States: financial analysis of delivered biomass Part I. Biomass Bioenerg. 2011;35(2):755-66.

22. McCANN C. Architecture of the primaty cell wall. The cytoskeletal basis of plant growth and form. 1991. p. 109-29.

23. Delmer DP. Cellulose biosynthesis: exciting times for a difficult field of study. Annu Rev Plant Biol. 1999;50(1):245-76.

24. Kimura S, Laosinchai W, Itoh T, Cui X, Linder CR, Brown RM. Immunogold labeling of rosette terminal cellulose-synthesizing complexes in the vascular plant Vigna angularis. Plant Cell. 1999;11(11):2075-85.

25. Lamed R, Setter E, Bayer EA. Characterization of a cellulose-binding, cellulase-containing complex in Clostridium thermocellum. J Bacteriol. 1983:156(2):828-36.

26. Bayer EA, Morag E, Lamed R. The cellulosome-a treasure-trove for biotechnology. Trends Biotechnol. 1994;12(9):379-86.

27. Xu Q, Singh A, Himmel ME. Perspectives and new directions for the production of bioethanol using consolidated bioprocessing of lignocellulose. Curr Opin Biotechnol. 2009;20(3):364-71.

28. Lynd LR, Van Zyl WH, McBride JE, Laser M. Consolidated bioprocessing of cellulosic biomass: an update. Curr Opin Biotechnol. 2005; 16(5):577-83.

29. Van Dyk J, Pletschke B. A review of lignocellulose bioconversion using enzymatic hydrolysis and synergistic cooperation between enzymesfactors affecting enzymes, conversion and synergy. Biotechnol Adv. 2012;30(6):1458-80

30. Himmel ME, Xu Q, Luo Y, Ding SY, Lamed R, Bayer EA. Microbial enzyme systems for biomass conversion: emerging paradigms. Biofuels. 2010:1(2):323-41.

31. liyama K, Lam TBT, Stone BA. Covalent cross-links in the cell wall. Plant Physiol. 1994;104(2):315.

32. Himmel ME, Ruth MF, Wyman CE. Cellulase for commodity products from cellulosic biomass. Curr Opin Biotechnol. 1999:10(4):358-64.

33. Mohnen D, Hahn MG, editors. Cell wall carbohydrates as signals in plants. Seminars in cell biology. Amsterdam: Elsevier; 1993.

34. Haigler C, Brown R. Transport of rosettes from the Golgi apparatus to the plasma membrane in isolated mesophyll cells of Zinnia elegans during differentiation to tracheary elements in suspension culture. Protoplasma. 1986;134(2):111-20.

35. Buchanan BB, Gruissem W, Jones RL. Biochemistry and molecular biology of plants. Hoboken: Wiley; 2015.

36. Dutta S, De S, Saha B, Alam MI. Advances in conversion of hemicellulosic biomass to furfural and upgrading to biofuels. Catal Sci Technol. 2012:2(10):2025-36. 
37. Carvalheiro F, Duarte LC, Gírio FM. Hemicellulose biorefineries: a review on biomass pretreatments. J Sci Indus Res. 2008;67:849-64.

38. Gao D, Uppugundla N, Chundawat SP, Yu X, Hermanson S, Gowda K et al. Hemicellulases and auxiliary enzymes for improved conversion of lignocellulosic biomass to monosaccharides. Biotechnol Biofuels. 2011;4(1):5

39. Agbor VB, Cicek N, Sparling R, Berlin A, Levin DB. Biomass pretreatment: fundamentals toward application. Biotechnol Adv. 2011;29(6):675-85.

40. $\mathrm{Pu}$ Y, Hu F, Huang F, Davison BH, Ragauskas AJ. Assessing the molecular structure basis for biomass recalcitrance during dilute acid and hydrothermal pretreatments. Biotechnol Biofuels. 2013;6(1):15.

41. Albersheim P, Darvill A, Roberts K, Sederoff R, Staehelin A. Plant cell walls. Newyork: Garland Science; 2010.

42. Laschimke R. Investigation of the wetting behaviour of natural lignin-a contribution to the cohesion theory of water transport in plants. Thermochim Acta. 1989;151:35-56.

43. Boerjan W, Ralph J, Baucher M. Lignin biosynthesis. Annu Rev Plant Biol. 2003:54(1):519-46.

44. Chen F, Tobimatsu Y, Havkin-Frenkel D, Dixon RA, Ralph J. A polymer of caffeyl alcohol in plant seeds. Proc Natl Acad Sci. 2012;109(5):1772-7.

45. Donaldson LA. Lignification and lignin topochemistry - an ultrastructural view. Phytochemistry. 2001;57(6):859-73.

46. Park S, Baker JO, Himmel ME, Parilla PA, Johnson DK. Cellulose crystallinity index: measurement techniques and their impact on interpreting cellulase performance. Biotechnol Biofuels. 2010;3(1):10.

47. Terashima N, Kitano K, Kojima M, Yoshida M, Yamamoto H, Westermark U. Nanostructural assembly of cellulose, hemicellulose, and lignin in the middle layer of secondary wall of ginkgo tracheid. J Wood Sci. 2009:55(6):409-16.

48. McCann M, Wells B, Roberts K. Direct visualization of cross-links in the primary plant cell wall. J Cell Sci. 1990;96(2):323-34

49. Fry SC. Cross-linking of matrix polymers in the growing cell walls of angiosperms. Ann Rev Plant Physiol. 1986;37(1):165-86.

50. Rose JK, Bennett AB. Cooperative disassembly of the cellulose-xyloglucan network of plant cell walls: parallels between cell expansion and fruit ripening. Trends Plant Sci. 1999;4(5):176-83.

51. Scalbert A, Monties B, Lallemand J-Y, Guittet E, Rolando C. Ether linkage between phenolic acids and lignin fractions from wheat straw. Phytochemistry. 1985;24(6):1359-62.

52. Grabber JH, Ralph J, Lapierre C, Barrière Y. Genetic and molecular basis of grass cell-wall degradability. I. Lignin-cell wall matrix interactions. CR Biol. 2004;327(5):455-65

53. D'Haeze W, Gao M, De Rycke R, Van Montagu M, Engler G, Holsters M. Roles for azorhizobial Nod factors and surface polysaccharides in intercellular invasion and nodule penetration, respectively. Mol Plant Microbe Interact. 1998;11(10):999-1008.

54. Baskin TI, Beemster GT, Judy-March JE, Marga F. Disorganization of cortical microtubules stimulates tangential expansion and reduces the uniformity of cellulose microfibril alignment among cells in the root of Arabidopsis. Plant Physiol. 2004;135(4):2279-90.

55. Fromm J, Rockel B, Lautner S, Windeisen E, Wanner G. Lignin distribution in wood cell walls determined by TEM and backscattered SEM techniques. J Struct Biol. 2003;143(1):77-84.

56. Persson S, Paredez A, Carroll A, Palsdottir H, Doblin M, Poindexter P, et al. Genetic evidence for three unique components in primary cellwall cellulose synthase complexes in Arabidopsis. Proc Natl Acad Sci. 2007:104(39):15566-71.

57. Tao S, Khanizadeh S, Zhang H, Zhang S. Anatomy, ultrastructure and lignin distribution of stone cells in two Pyrus species. Plant Sci. 2009:176(3):413-9.

58. Lee KJ, Marcus SE, Knox JP. Cell wall biology: perspectives from cell wall imaging. Molecular plant. 2011;4(2):212-9.

59. Anderson CT, Carroll A, Akhmetova L, Somerville C. Real-time imaging of cellulose reorientation during cell wall expansion in Arabidopsis roots. Plant Physiol. 2010;152(2):787-96.

60. Campbell MM, Sederoff RR. Variation in lignin content and composition (mechanisms of control and implications for the genetic improvement of plants). Plant Physiol. 1996;110(1):3.

61. McCann M, Chen L, Roberts K, Kemsley E, Sene C, Carpita N, et al. Infrared microspectroscopy: sampling heterogeneity in plant cell wall composition and architecture. Physiol Plant. 1997;100(3):729-38.
62. Burton RA, Gidley MJ, Fincher GB. Heterogeneity in the chemistry, structure and function of plant cell walls. Nat Chem Biol. 2010;6(10):724-32.

63. Borisjuk L, Rolletschek $H$, Neuberger T. Surveying the plant's world by magnetic resonance imaging. Plant J. 2012;70(1):129-46. https://doi. org/10.1111/j.1365-313X.2012.04927.X.

64. Hubeau M, Steppe K. Plant-PET scans. In vivo mapping of xylem and phloem functioning. Trends Plant Sci. 2015;20(10):676-85. https://doi. org/10.1016/j.tplants.2015.07.008.

65. Dhondt S, Vanhaeren H, Van Loo D, Cnudde V, Inzé D. Plant structure visualization by high-resolution X-ray computed tomography. Trends Plant Sci. 2010;15(8):419-22. https://doi.org/10.1016/j.tplants.2010.05.002.

66. Bjarnholt N, Li B, D’Alvise J, Janfelt C. Mass spectrometry imaging of plant metabolites - principles and possibilities. Nat Prod Rep. 2014;31(6):818-37. https://doi.org/10.1039/c3np70100j.

67. Jung S, Foston M, Kalluri UC, Tuskan GA, Ragauskas AJ. 3D chemical image using TOF-SIMS revealing the biopolymer component spatial and lateral distributions in biomass. Angew Chem Int Ed. 2012;51(48):12005-8. https://doi.org/10.1002/anie.201205243.

68. Donaldson L, Radotic K. Fluorescence lifetime imaging of lignin autofluorescence in normal and compression wood. J Microsc. 2013;251(2):178-87.

69. Bastiaens PI, Squire A. Fluorescence lifetime imaging microscopy: spatial resolution of biochemical processes in the cell. Trends Cell Biol. 1999;9(2):48-52.

70. van Munster EB, Gadella TW. Fluorescence lifetime imaging microscopy (FLIM). Microscopy techniques. Berlin: Springer; 2005. p. 143-75.

71. Agarwal UP. Raman imaging to investigate ultrastructure and composition of plant cell walls: distribution of lignin and cellulose in black spruce wood (Picea mariana). Planta. 2006:224(5):1141.

72. Gierlinger N, Schwanninger M. Chemical imaging of poplar wood cell walls by confocal Raman microscopy. Plant Physiol. 2006;140(4):1246-54

73. Cheng J-X, Xie XS. Vibrational spectroscopic imaging of living systems: an emerging platform for biology and medicine. Science. 2015;350(6264):aaa8870.

74. Zeng Y, Himmel ME, Ding S-Y. Coherent Raman microscopy analysis of plant cell walls. Methods in molecular biology. In: Himmel ME, editor. Biomass conversion. Newyork: Humana Press; 2012. p. 49-60.

75. Zeng Y, Saar BG, Friedrich MG, Chen F, Liu Y-S, Dixon RA, et al. Imaging lignin-downregulated alfalfa using coherent anti-stokes Raman scattering microscopy. BioEnerg Res. 2010;3(3):272-7. https://doi.org/10.1007/ s12155-010-9079-1.

76. Zeng Y, Zhao S, Wei H, Tucker M, Himmel M, Mosier N, et al. In situ micro-spectroscopic investigation of lignin in poplar cell walls pretreated by maleic acid. Biotechnol Biofuels. 2015;8(1):1-12. https://doi. org/10.1186/s13068-015-0312-1.

77. Saar BG, Zeng YN, Freudiger CW, Liu YS, Himmel ME, Xie XS, et al. Label-free, real-time monitoring of biomass processing with stimulated Raman scattering microscopy. Angew Chem-Int Edit. 2010;49(32):54769. https://doi.org/10.1002/anie.201000900.

78. Zeng Y, Yarbrough JM, Mittal A, Tucker MP, Vinzant TB, Decker SR, et al. In situ label-free imaging of hemicellulose in plant cell walls using stimulated Raman scattering microscopy. Biotechnol Biofuels. 2016;9(1):256. https://doi.org/10.1186/s13068-016-0669-9.

79. Eaton P, West P. Atomic force microscopy. Oxford: Oxford University Press; 2010

80. Carpita NC, Gibeaut DM. Structural models of primary cell walls in flowering plants: consistency of molecular structure with the physical properties of the walls during growth. Plant J. 1993;3(1):1-30.

81. Preston RD. The physical biology of plant cell walls. London: Chapman \& Hall; 1974.

82. Cosgrove DJ. Growth of the plant cell wall. Nat Rev Mol Cell Biol. 2005;6(11):850-61.

83. Zhong R, Ye Z-H. Secondary cell walls: biosynthesis, patterned deposition and transcriptional regulation. Plant Cell Physiol. 2014:56(2):195-214

84. Mauseth JD. Plant anatomy. Menlo Park: Benjamin/Cummings Publ. Co.; 1988.

85. Grabber JH, Jung GA, Abrams SM, Howard DB. Digestion kinetics of parenchyma and sclerenchyma cell walls isolated from orchardgrass and switchgrass. Crop Sci. 1992;32(3):806-10. 
86. Grabber J, Jung G, Hill R. Chemical composition of parenchyma and sclerenchyma cell walls isolated from orchardgrass and switchgrass. Crop Sci. 1991;31(4):1058-65.

87. Wardrop A, Liese W, Davies G. The nature of the wart structure in conifer tracheids. Holzforsch Int J Biol Chem Phys Technol Wood. 1959;13(4):115-20.

88. Wardrop A. The organization and properties of the outer layer of the secondary wall in conifer tracheids. Holzforsch Int J Biol Chem Phys Technol Wood. 1957;11(4):102-10.

89. Imamura $Y$, Harada $H$, Saiki H. Electron microscopic study on formation and organization of cell wall in coniferous trachieds: criss-crossed and transition structures in secondary wall [Jap.; Eng. summ.]. Bull Kyoto Univ For. 1972;44:183-93.

90. Kirby AR, Gunning AP, Waldron KW, Morris VJ, Ng A. Visualization of plant cell walls by atomic force microscopy. Biophys J. 1996;70(3):113843. https://doi.org/10.1016/S0006-3495(96)79708-4.

91. Pesacreta TC, Carlson LC, Triplett BA. Atomic force microscopy of cotton fiber cell wall surfaces in air and water: quantitative and qualitative aspects. Planta. 1997;202(4):435-42. https://doi.org/10.1007/ s004250050147.

92. Thimm JC, Burritt DJ, Ducker WA, Melton LD. Celery (Apium graveolens L.) parenchyma cell walls examined by atomic force microscopy: effect of dehydration on cellulose microfibrils. Planta. 2000;212(1):25-32. https://doi.org/10.1007/s004250000359.

93. Taylor NG, Howells RM, Huttly AK, Vickers K, Turner SR. Interactions among three distinct CesA proteins essential for cellulose synthesis. Proc Natl Acad Sci. 2003;100(3):1450-5.

94. Herth W. Arrays of plasma-membrane "rosettes" involved in cellulose microfibril formation of Spirogyra. Planta. 1983;159(4):347-56.

95. Nixon BT, Mansouri K, Singh A, Du J, Davis JK, Lee J-G, et al. Comparative structural and computational analysis supports eighteen cellulose synthases in the plant cellulose synthesis complex. Sci Rep. 2016;6:28696.

96. Newman $\mathrm{RH}$, Hill SJ, Harris PJ. Wide-angle $X$-ray scattering and solidstate nuclear magnetic resonance data combined to test models for cellulose microfibrils in mung bean cell walls. Plant Physiol. 2013;163(4):1558-67.

97. Nishiyama Y, Sugiyama J, Chanzy H, Langan P. Crystal structure and hydrogen bonding system in cellulose la from synchrotron X-ray and neutron fiber diffraction. J Am Chem Soc. 2003;125(47):14300-6. https://doi.org/10.1021/ja037055w.

98. Agarwal UP, Reiner RS, Ralph SA. Cellulose I crystallinity determination using FT-Raman spectroscopy: univariate and multivariate methods. Cellulose. 2010;17(4):721-33.

99. Wada M, Chanzy H, Nishiyama Y, Langan P. Cellulose IIII crystal structure and hydrogen bonding by synchrotron $X$-ray and neutron fiber diffraction. Macromolecules. 2004;37(23):8548-55.

100. Barnette AL, Bradley LC, Veres BD, Schreiner EP, Park YB, Park J, et al. Selective detection of crystalline cellulose in plant cell walls with sum-frequency-generation (SFG) vibration spectroscopy. Biomacromol. 2011;12(7):2434-9.

101. Chunilall V, Bush T, Larsson PT. Supra-molecular structure and chemical reactivity of cellulose I studied using CP/MAS 13C-NMR. In: van de Ven T, Godbout L, editors. Cellulose-fundamental aspects. InTech, Manhattan, New York; 2013.

102. Selig MJ, Adney WS, Himmel ME, Decker SR. The impact of cell wall acetylation on corn stover hydrolysis by cellulolytic and xylanolytic enzymes. Cellulose. 2009;16(4):711-22.

103. Cesarino I, Araújo P, Domingues Júnior AP, Mazzafera P. An overview of lignin metabolism and its effect on biomass recalcitrance. Braz J Bot. 2012;35(4):303-11.

104. Volynets B, Dahman Y. Assessment of pretreatments and enzymatic hydrolysis of wheat straw as a sugar source for bioprocess industry. Int J Energy Environ. 2011;2(3):427-46.

105. Foston M, Ragauskas AJ. Biomass characterization: recent progress in understanding biomass recalcitrance. Indus Biotechnol. 2012:8(4):191-208.

106. Parthasarathi R, Bellesia G, Chundawat S, Dale B, Langan P, Gnanakaran S. Insights into hydrogen bonding and stacking interactions in cellulose. J Phys Chem A. 2011;115(49):14191-202.

107. Yoneda Y, Mereiter K, Jaeger C, Brecker L, Kosma P, Rosenau T, et al. van der Waals versus hydrogen-bonding forces in a crystalline analog of cellotetraose: cyclohexyl 4'-O-cyclohexyl $\beta$-d-cellobioside cyclohexane solvate. J Am Chem Soc. 2008;130(49):16678-90.

108. Mooney CA, Mansfield SD, Touhy MG, Saddler JN. The effect of initial pore volume and lignin content on the enzymatic hydrolysis of softwoods. Bioresour Technol. 1998;64(2):113-9.

109. Jung H, Deetz D. Cell wall lignification and degradability. Forage cell wall structure and digestibility. 1993(foragecellwalls):315-46.

110. Ragauskas AJ, Beckham GT, Biddy MJ, Chandra R, Chen F, Davis MF, et al. Lignin valorization: improving lignin processing in the biorefinery. Science. 2014;344(6185):1246843.

111. Košíková B, Joniak D, Kosakova L. On the properties of benzyl ether bonds in the lignin-saccharidic complex isolated from spruce. Holzforsch-Int J Biol Chem Phys Technol Wood. 1979;33(1):11-4

112. Lundquist $K$, Simonson $R$, Tingsvik K. Studies on lignin carbohydrate linkages in milled wood lignin preparations. Svensk Papperstidning. 1980;83(16):452-4.

113. Balakshin M, Capanema E, Gracz H, Chang HM, Jameel H. Quantification of lignin-carbohydrate linkages with high-resolution NMR spectroscopy. Planta. 2011;233(6):1097-110.

114. Himmelsbach DS, Barton FE. Carbon-13 nuclear magnetic resonance of grass lignins. J Agric Food Chem. 1980;28(6):1203-8.

115. Torget RW, Kim JS, Lee Y. Fundamental aspects of dilute acid hydrolysis/ fractionation kinetics of hardwood carbohydrates. 1. Cellulose hydrolysis. Ind Eng Chem Res. 2000;39(8):2817-25.

116. Pandey MP, Kim CS. Lignin depolymerization and conversion: a review of thermochemical methods. Chem Eng Technol. 2011;34(1):29-41.

117. Hu G, Heitmann JA, Rojas OJ. Feedstock pretreatment strategies for producing ethanol from wood, bark, and forest residues. BioResources. 2008;3(1):270-94

118. Donohoe BS, Decker SR, Tucker MP, Himmel ME, Vinzant TB. Visualizing lignin coalescence and migration through maize cell walls following thermochemical pretreatment. Biotechnol Bioeng. 2008;101(5):913-25.

119. Li H, Pu Y, Kumar R, Ragauskas AJ, Wyman CE. Investigation of lignin deposition on cellulose during hydrothermal pretreatment, its effect on cellulose hydrolysis, and underlying mechanisms. Biotechnol Bioeng. 2014;111(3):485-92.

120. Mosier NS, Ladisch CM, Ladisch MR. Characterization of acid catalytic domains for cellulose hydrolysis and glucose degradation. Biotechnol Bioeng. 2002;79(6):610-8. https://doi.org/10.1002/bit.10316.

121. Lu Y, Mosier NS. Biomimetic catalysis for hemicellulose hydrolysis in corn stover. Biotechnol Prog. 2007;23(1):116-23. https://doi. org/10.1021/bp060223e.

122. Lu Y, Mosier NS. Kinetic modeling analysis of maleic acid-catalyzed hemicellulose hydrolysis in corn stover. Biotechnol Bioeng. 2008;101(6):1170-81. https://doi.org/10.1002/bit.22008.

123. Miller AR, Crawford DL, Roberts LW. Lignification and xylogenesis in Lactuca pith explants cultured in vitro in the presence of auxin and cytokinin: a role for endogenous ethylene. J Exp Bot. 1985;36(1):110-8.

124. Hon DNS, Shiraishi N. Wood and cellulosic chemistry, revised, and expanded. Boca Raton: CRC Press; 2000.

125. Igarashi K, Koivula A, Wada M, Kimura S, Penttilä M, Samejima M. High speed atomic force microscopy visualizes processive movement of Trichoderma reesei cellobiohydrolase I on crystalline cellulose. J Biol Chem. 2009;284(52):36186-90.

126. Liu Y-S, Baker JO, Zeng Y, Himmel ME, Haas T, Ding S-Y. Cellobiohydrolase hydrolyzes crystalline cellulose on hydrophobic faces. J Biol Chem. 2011;286(13):11195-201.

127. Yang B, Wyman CE. BSA treatment to enhance enzymatic hydrolysis of cellulose in lignin containing substrates. Biotechnol Bioeng. 2006:94(4):611-7.

128. Nakagame S, Chandra RP, Saddler JN. The effect of isolated lignins, obtained from a range of pretreated lignocellulosic substrates, on enzymatic hydrolysis. Biotechnol Bioeng. 2010;105(5):871-9.

129. Rahikainen JL, Martin-Sampedro R, Heikkinen H, Rovio S, Marjamaa K, Tamminen T, et al. Inhibitory effect of lignin during cellulose bioconversion: the effect of lignin chemistry on non-productive enzyme adsorption. Bioresour Technol. 2013;133:270-8.

130. Saha BC, Iten LB, Cotta MA, Wu YV. Dilute acid pretreatment, enzymatic saccharification and fermentation of wheat straw to ethanol. Process Biochem. 2005;40(12):3693-700. 
131. Ishizawa Cl, Jeoh T, Adney WS, Himmel ME, Johnson DK, Davis MF. Can delignification decrease cellulose digestibility in acid pretreated corn stover? Cellulose. 2009;16(4):677-86.

132. Raghunathan V, Potma EO. Multiplicative and subtractive focal volume engineering in coherent Raman microscopy. J Opt Soc Am A. 2010;27(11):2365-74. https://doi.org/10.1364/josaa.27.002365.
133. Kim H, Bryant GW, Stranick SJ. Superresolution four-wave mixing microscopy. Opt Express. 2012;20(6):6042-51. https://doi.org/10.1364/ oe.20.006042.

134. Silva WR, Graefe CT, Frontiera RR. Toward label-free super-resolution microscopy. ACS Photonics. 2016;3(1):79-86. https://doi.org/10.1021/ acsphotonics.5b00467. 